\title{
Eliza Haywood's Love in Excess: Women, the Enlightenment, and the Trap of Reason
}

\author{
Love in Excess de Eliza Haywood: Las mujeres, la Ilustración \\ y la trampa de la razón
}

\author{
Bárbara PÉREZ CURIEL \\ Universidad de Oxford \\ Reino Unido
}

\begin{abstract}
This paper examines the contribution of Eliza Haywood's first work of amatory fiction, Love in Excess; or the Fatal Enquiry, to the tradition of women's critical writing that have questioned the hidden exclusions at the core of the European Enlightenment. Love in Excess addresses the dichotomy of reason versus emotion and the paradoxical expectations it imposed upon upper-class women during the European Enlightenment. Haywood's exploration challenges this binary construction by showing the mutual interdependence of reason and passion, and by exposing the double standards on the basis of which women's and men's desires were regulated.
\end{abstract}

Keywords: Eliza Haywood, Love in Excess, Enlightenment, feminism, reason, passion, desire

\section{Resumen}

Este artículo analiza la contribución de la primera obra de ficción amatoria de Eliza Haywood, Love in Excess; or the Fatal Enquiry, a la tradición de escritura crítica hecha por mujeres que han cuestionado las exclusiones ocultas en el núcleo de la Ilustración europea. Love in Excess aborda la dicotomía entre razón y pasión, y las expectativas paradójicas que ésta imponía a las mujeres de clase alta durante la Ilustración europea. La exploración de Haywood desafía esta construcción binaria al mostrar la interdependencia que existe entre la razón y la pasión, y al exponer la doble moral a partir de la cual se regulaba el deseo de hombres y mujeres.

Palabras clave: Eliza Haywood, Love in Excess, Ilustración, feminismo, razón, pasión, deseo 


\section{Introduction}

Few would question that cultural products contribute to normalizing, more directly or indirectly, hegemonic practices and ideologies of the context in which they are created and received. However, they can also constitute spaces of resistance where conventions are not naturalized but rather exposed as what they are: constructions that can be challenged and transformed.

Eliza Haywood's first novel is an example of this. Her amatory fiction Love in Excess; or the Fatal Enquiry was published in three separate volumes between 1719 and 1720, several decades before Olympe de Gouges' and Mary Wollstonecraft's proto-feminist ${ }^{1}$ treatises - the Declaration of the rights of women and female citizens (1791) and A Vindication of the Rights of Woman (1792), respectively-appropriated the language of the theories championed in Europe during the Age of Enlightenment in order to challenge their exclusionary practices. These first European feminists questioned the principles and policies fostered by revolutionaries and so-called "freethinkers" that entitled some men, but not women, to inalienable human rights on the basis of notions of universal equality, freedom, and rationality.

In this article, I argue that Haywood's work can be read as part of a long tradition of critical feminism that, not without plurality, internal disputes, and contradictions, has strived to de-naturalize essentialist beliefs about women and gender relations that are profoundly embedded in the Enlightenment's political, legal, medical, scientific, and cultural narratives. A crucial dimension of this critique has consisted in reading many of modernity's slogans against themselves; that is, in uncovering their inner contradictions and the way their imposition in Europe and by Europe has always entailed different exclusions and oppressions.

\section{Exclusion in Universality}

In her foundational text, Patriarchy and Accumulation on a World Scale: Women in the International Division of Labour, Maria Mies (2014) reflects on the predatory imposition of modernity's economic, social, legal, and political systems both in Western Europe and the regions of the world these potencies colonized: "Direct violence was the means by which women, colonies and nature were compelled to serve the 'white man', and [...] without such violence the European Enlightenment, modernization and development would not have happened" (2014: xx). The Age of Enlightenment began in Europe, as Mies reminds us, "with the brutal persecution and killing of women as witches" (Mies, 2014: xx), in an attempt to impose a mechanistic, rational, scientific, and, what is crucial, market-oriented model based

\footnotetext{
${ }^{1}$ The term feminist first came into usage at the end of the nineteenth century (Kramarae \& Spender, 2000: 798).
} 
on exploitation of land and people. This process has been thoroughly studied by scholars like Carolyn Merchant (1989), Silvia Federici (2004), and Mies herself.

This violence, often minimized (if accounted at all in historical narratives of world history), defies the discourses on the rational and civilizing mission of modernity and the Enlightenment. While the Enlightenment was not a monolithic project, it certainly revolved around a constellation of ideas about a Eurocentric, linear progress of humanity that rested on simultaneously universalizing and exclusionary concepts of reason and rationality standing in opposition against emotions and desire. In spite of its claim to universality, Enlightenment rationality was a trait inherently associated with the idealized figure of the white man, and was systematically used to justify their dominance over colonized populations, enslaved people, and women of most classes.

This contradiction of theoretically defending freedom and equality as universal rights and practically upholding oppressive regulations, enterprises, and institutions, such as colonialism, slavery, and the legal submission of women, was a thorn in the flesh of Enlightenment philosophy and political theory that has been carried to the present day, as capitalist liberalism continues to be the hegemonic ideology in Western Europe, Anglo America, and many of the former colonies in which this ideology was imposed.

Examples of this incongruity can be found across the diverse landscape of opinions of Enlightenment thought as well as in the ideas of individual thinkers. Thomas Jefferson provides a clear instance of the latter. In the Declaration of Independence of the United States (1776), he argued in favor of the - theoretical - equality among men: "We hold these truths to be self-evident, that all men are created equal, that they are endowed by their Creator with certain unalienable Rights, that among these are Life, Liberty and the pursuit of Happiness." But around a decade later, in his Notes on the State of Virginia, he claimed to have the "suspicion only" that "the blacks, whether originally a distinct race, or made distinct by time and circumstances, are inferior to the whites in the endowments both of body and mind" (1982: 143), and that "This unfortunate difference of color, and perhaps of faculty, is a powerful obstacle to the emancipation of these people" (143; emphasis mine).

The modern paradigm of universal rationality excluded Western European women, too. As Michael McKeon (1995) observes, "Alongside capitalism, modern patriarchy emerges" (295). In her study of this process, Mies (2014) coined the concept of the "housewifization" of women: "the main strategy of international capital to integrate women worldwide into the accumulation process" (4), and which depended on the use of "the domestic labour of women all over the world", as well as the labor of colonized people and those excluded from the formal economy, as "“a free resource' for capital” (xvi). ${ }^{2}$ The rise of capitalism and liberalism

\footnotetext{
${ }^{2}$ It is important to clarify here that Mies considers housewifization to be a constitutive aspect of the socialist model of accumulation, too: "On the basis of the examples of the USSR, China and Viet-
} 
at the dawn of modernity and its consolidation in the eighteenth and nineteenth centuries can only be seen as a process of advancement of liberties if the experiences of women, impoverished people, and non-white populations are ignored.

Women's subjugation (whose forms varied greatly depending on racialization and class) was actualized in the new political models established in Europe since the early modern period, when upper-class women were barred from most economic activities. The creation of a public, masculine sphere and a private, feminine one, which pushed these women to financial dependence on marriage, occurred alongside the development of a deterministic understanding of sexual differenceor, more accurately, of a particular construction and hierarchization of sexual difference that emphasized certain bodily traits and was fostered by the medical and biological investigations of the time, as demonstrated by several analysis emerging from the intersections of poststructuralism, feminism, and queer theories, developed in the late twentieth century (see Rubin [1984]; Butler [1990]; Fausto-Sterling [1993]; Dreger [1998]). "In the later seventeenth and eighteenth centuries", explains McKeon, "England acquired the modern wisdom that there are not one but two sexes; that they are biologically distinct and therefore incommensurable; and that they are defined not by behavior, which is variable, but by nature, which is not" (1995: 301). Justifications for women's exclusion from reason and its public expressions were then enshrined in modern science, the institution that was replacing religious dogma as the ultimate authority on knowledge.

This was the context in which Mary Astell (1996) asked: "If all Men are born free, how is it that all Women are born slaves?" (18). In order for the new ideas of universal human rights to be logically compatible with the existence of real slavery (which, of course, included women who were completely neglected by the first European feminist projects) and the denial of civil and political rights to all women, these groups had to be excluded from the status of full humanity, which in the Age of Reason became synonym with being irrational. The enlightened notion of reason was constructed both as the essential element that defined humanity and as a trait that, by definition, excluded women and racialized people.

In her classic book The Man of Reason (1984), Genevieve Lloyd analyzes the construction of this notion in the Western philosophical tradition (construed in her study as going back to Plato) and argues that reason has systematically been defined through the overcoming of features traditionally associated with femininity, such as the tendency to emotionality. Lloyd, as explained by Karen Jones (2004),

nam, it is shown that, in spite of the socialist rhetoric about women's participation in social production, the socialist accumulation process is also in reality based on the same mechanism of housewifization and on the model of dualizing the economy into a male-dominated, 'progressive' socialized sector, and into a subsidiary, private or informal sector, where mostly women are found" (2014: 5). Similarly, Mies discusses the use of violence embedded in the logic of rationality in both modern capitalist economies and "the socialist utopia" which "is also based [...] on progress and the development of science and technology" through exploitation of resources and people (xxi). 
argues that "whatever the conception of reason, the feminine and all it stands for has been excluded from it, and that this exclusion has shaped our understanding of both what it is to be an ideal inquirer and what it is to be feminine" (305).

\section{The Irrational Woman}

According to Ros Ballaster (1998), Haywood's early works of amatory fiction "mark the beginnings of an autonomous tradition in romantic fiction, primarily addressed to and authored by women" (159). This was a corpus of works that openly addressed love and passion as subjects in their own right, and not as merely political allegories, as they had appeared in the work of Haywood's predecessors Aphra Behn and Delarivier Manley (Ballaster, 1998: 129). Love in Excess, whose publication roughly coincided with the beginning of a decade during which women writers dominated the literary market (Moretti, 2003: 89), navigates the emotional states and intellectual strategies associated with the normative sexual roles available to upper-class women in the eighteenth century, a context where the single definition of female success was marriage.

Haywood's work points to the contradictions at the core of the expectations imposed on these women, who, on the one hand, are regarded as rationally inferior and therefore prone to passions, while, on the other, are expected to (rationally) tame such penchant if they do not want to risk being cast away. The social status of women, normatively portrayed in mainstream cultural and scientific narratives as creatures incapable of proper reasoning, depended on the same capacity for reason and temperance they were supposed to naturally lack. Count D'elmont himself, the male protagonist of Haywood's story, reflects on this conundrum:

The Count knew by Experience, the unutterable Perturbations of Suspence, and what agonizing Tortures rend an amorous Soul, divided betwixt Hope and Fear: Despair itself is not so cruel as Uncertainty, and in all Ills, especially in those of Love, it is less Misery, to know than dread the worst. The Remembrance of what he had suffered, thus agitated, in the Beginning of his Passion for Melliora, made him extremely pity the unknown Lady, and regret her sudden Departure; because it had prevented him from letting her into so much of his Circumstances, as he believ'd were necessary to induce her to recall her Heart. But when he consider'd how much he had struggled, and how far he had been from being able to repel Desire, he began to wonder that it cou'd ever enter into his Thoughts, that there was even a Possibility for Woman, so much stronger in her Fancy, and weaker in her Judgment, to suppress the Influence of that powerful Passion, against which, no Laws, no Rules, no Force of Reason, or Philosophy, are sufficient Guard. (Haywood, 1725: 160; emphasis mine)

Through the character of Alovisa, D'elmont's first wife, Haywood's narrator shows the consequences on women's psyche of the social norms that forbade them 
"to make a Declaration of their Thoughts" (Haywood, 1725: 3) to a man. Alovisa's repressed passion for D'elmont (who eventually marries her for ambition) drives her to incarnate, as in a self-fulfilling prophecy, the irrational woman her society expected her to be:

But how (when left alone, and abandon'd to the Whirlwinds of her Passion) the desperate Alovisa behav'd, none but those who, like her, have burn'd in hopeless Fires can guess, the most lively Description wou'd come far short of what she felt; she rav'd, she tore her Hair and Face, and in the Extremity of her Anguish was ready to lay violent Hands on her own Life. In this Tempest of Mind, she continu'd for some time, till at length Rage beginning to dissipate itself in Tears, made way for cooler Considerations; and her natural Vanity resuming its Empire in her Soul, was of no little Service to her on this Occasion. Why am I thus disturb'd? Mean spirited as I am! said she, D'elmont is ignorant of the Sentiments I am possessed with in his Favour; and perhaps 'tis only want of Incouragement that has so long depriv'd me of my Lover. (Haywood, 1725: 9)

By exhibiting the psychological consequences of the extreme restraint that was imposed upon women's desire, Haywood's implicit author suggests that Alovisa embodies the irrational cliché not because that is her nature, but because she is forced to repress an essential aspect of her humanity, the same one D'elmont can so freely express and act upon, knowing that his intense passions do not pose a threat to him - they, however, constantly put the women he desires and is willing to abuse ("seduce") at risk.

The contrast of the conditions in which D'elmont and Alovisa can (and cannot) love and desire suggests that men's rationality is, at least in part, a result of their license to be passionate, while women's irrationality is a consequence of the written and unwritten rules that force them to suppress their emotions. If the modern ideal of reason freed men, Haywood's novel shows how it trapped women in a dichotomy that served to consolidate their modern subjection. This way, Haywood goes beyond merely questioning women's assumed inferior rationality: her work contests the binary opposition of reason and passion by showing their interdependence and how its arbitrary construction worked against the women she portrays.

Moreover, it is noteworthy that Love in Excess does not make a case in favor of equality through rationality, but through passion. It can be argued that what is emphasized is not that women are equally rational as men, but rather equally irrational-i.e., passionate. Instead of chasing after the dominant standard of rationality, Love in Excess makes a moral case for the liberation of women's sexuality based on the power of passion, a force "not Subservient, but absolutely Comptroller of the Will" (Haywood, 1725: 177). In an era largely defined by the search for individual freedom through an idiosyncratic notion of human rationality, Haywood's challenge to the double standards that greatly restricted women's sexuality while indulging men's, takes the form on an additional defiance of the fetish of 
rationality as the means to achieve liberation. Love and passion are indeed no allegories nor metaphors for Haywood. They represent the human condition.

In Juliette Merritt's words, "Haywood's writing demonstrates a sustained exposé of the conditions of female existence; to read her is to witness an analysis of those conditions and a set of strategies through which women can enhance their social power" (2004: 22). In Love in Excess, the character of Melliora - as if she were herself a reader of Haywood - clearly follows a strategic approach to her repressive reality. Unlike other women, Melliora is capable of restraining her feelings and, with some luck (considering the systematically abusive behavior of the count), manages to prevent being socially ruined by D'elmont. Melliora succeeds in escaping the fate of Amena, a woman "little vers'd in the Art of Dissimulation, so necessary to her Sex" (Haywood, 1725: 13), who is sent away to a "Monastery" after an encounter with D'elmont "in the Tuilleries" (Haywood, 1725: 13), and of Alovisa who dies trying to discover the identity of D'elmont's lover. Through Melliora, Haywood reveals that the irrational woman is rather the very rational woman for whom wit is not only a capacity but a necessity: a strategy to survive not only as an object of desire in an objectivizing environment, but also as a subject who, unlawfully but inevitably, desires.

Nevertheless, the implied author of Haywood's story does not necessarily or straightforwardly turn Melliora into an example to condemn the rest of the female characters. Certainly, Alovisa's fate could be seen as a cautionary tale about unrestricted lust and jealousy, and Amena's, as one about excessive naivety. However, the case of Melantha, provides a noteworthy counterexample. Despite her giving free rein to her desires to the point of deception and abuse, her story ends in a felicitous note in the second volume of the novel. Melantha gets married and manages to convince her oblivious husband that the child she gives birth to only seven months later is his: "Melantha, who was not of a Humour to take any thing to Heart, was married in a short Time, and had the good Fortune not to be suspected by her Husband, though she brought him a Child in Seven Months after her Wedding" (Haywood, 1725: 147). This way, Love in Excess portrays a diversity of female characters whose fates, either tragic or happy, depend to a large extent on their abilities and luck to successfully navigate the uneven conditions they were born into.

\section{Epilogue}

In order to guarantee its continuity, the strongest asset any hegemonic system has consists in its ability to make the state of affairs appear as natural, and its defiance as useless or even sacrilegious. The less visible the mechanisms of any construction are, the most inevitable it appears. "Every established order", said Pierre Bourdieu, "tends to produce (to very different degrees and with very different means) the 
naturalization of its own arbitrariness" (1977: 64). Therefore, the greatest threat to any established order lies in its exposition as a fabrication.

When examining early examples of challenges to male supremacy in modern Western European history, we should not underestimate the weight of millenary theories supporting the notion of women's natural subordinate status, which was further pushed into the collective common sense by the rationalist discourse of the Enlightenment. ${ }^{3}$ When Haywood and other early eighteenth-century women wrote, their intellectual, creative, and moral inferiority was enshrined in language, law, science, and any other major social narrative, a differentiation that served as the basis of the double standards through which the actions of men and women were adjudicated. Thus, shedding light to the arbitrariness of the theoretical justifications of their subordination represented an endeavor that was as difficult as it was crucial.

By de-naturalizing key discourses of its cultural environment that excluded women from full citizenship, Haywood's Love in Excess contributed to the articulation of critiques that were often first essayed in fiction but ended up infiltrating vocabularies, laws, and policymaking. Since Haywood's time, the inner contradictions of modernity and liberalism, as well as the exclusions hidden in their universalizing notions of liberty, equality, and citizenship, have been pushed to the center of the stage and confronted against each other time and again.

One of the most important fronts from which key notions of modernity have been further problematized is the field of decolonial feminism. In recent years, scholars like Chandra Talpade Mohanty (1984), Nkiru Uwechia Nzegwu, (2006), Oyèrónkẹ́ Oyèwùmí (1997), Aura Cumes and Ana Silvia Monzón (2006), and María Lugones (2007), among others, have posed crucial critiques not only to the capitalist patriarchy that persists as the living legacy of colonialism, but also to Eurocentric feminisms that have often been complicit with the reproduction of the political, legal, and economic systems that depend to a large extent on the oppression of racialized women around the world.

During the three centuries that have passed since Love in Excess was published, the Enlightenment's ideology of progress and its particular construction of the idea of reason have barely lost their dominant status in all major social narratives and political programs. In Mies words, "the world-view of this epoch, of the Enlightenment and of rationality is still the same". Moreover, "the keywords for Western civilization" are still "rationality and progress" (2014: xx), and they still carry the same contradictory logic of exclusions and violent inclusions.

\footnotetext{
${ }^{3}$ Within the paradigm of Western Europe, which imagines itself as part of a lineal history starting in ancient Greece, this can be easily traced back at least to Aristotle, who regarded women as physically and intellectually inferior to men, and thus as naturally subordinate. In his Politics, Aristotle wrote: "As regards the sexes, the male is by nature superior and the female inferior, the male ruler and the female subject" (quoted in Haarmann, 2017: 84).
} 
Haywood's exploration of the contradictions and limitations defining the social positions available to women is constrained to the milieu of upper-class European women, and it would be a mistake to interpreted such experiences as representative of a universal experience of women - even more so if we bear in mind that women who belonged to such a class were often direct beneficiaries of the wealth extracted from the colonies by means of the exploitation of enslaved women and men. Understood, then, as one part among many others in a long and complex tradition of women liberation struggles through critical writing, Haywood's work is helpful to illuminate a common aspect of modern patriarchy and gender oppression: the categorization and stratification of human beings supported on the enlightened ideology of rationalism.

\section{Bibliography}

Astell, Mary. (1996 [1706]). "Some Reflections upon Marriage.” In Patricia Springborg (Ed.), Political Writings. Cambridge: Cambridge University Press. BALlASTER, Ros. (1998). Seductive Forms: Women's Amatory Fiction from 1684 to 1740. Oxford: Oxford University Press.

Bourdieu, Pierre. (1977). Outlines of a Theory of Practice (Richard Nice, Trans.). Cambridge: Cambridge University Press.

ButLer, Judith. (1990). Gender Trouble: Feminism and the Subversion of Identity. London: Routledge.

Cumes, Aura, \& Silvia Monzón, Ana (Eds.). (2006). La encrucijada de las identidades: mujeres, feminismos y mayanismos en diálogo. Guatemala: Intervida World Alliance.

DREger, Alice. (1998). Hermaphrodites and the Medical Invention of Sex. Cambridge, MA: Harvard University Press.

Fausto-Sterling, Anne. (1993). "The Five Sexes: Why Male and Female Are Not Enough". The Sciences, 33(2), 20-24.

Federici, Silvia. (2004). Caliban and the Witch: Women, the Body and Primitive Accumulation. Brooklyn: Autonomedia.

HaArmann, Harald. (2017). Plato's Philosophy Reaching Beyond the Limits of Reason: Contours of a Contextual Theory of Truth. Hildesheim: Olms.

Haywood, Eliza. (1725). Love in Excess: or the Fatal Enquiry, a Novel. In Three Parts, Fourth Edition [online]. London: D. Brown and S. Chapman. Chadwyck-Healey Eighteenth-Century Fiction Full-Text Database.

JEFFERSON, Thomas. (1982 [1787]). Notes on the State of Virginia (William Peden, Ed.). Chapel Hill: The University of North Carolina Press.

JonES, Karen. (2004). "Gender and Rationality." In Alfred Mele \& Piers Rawling (Eds.), The Oxford Handbook of Rationality. Oxford: Oxford University Press. Kramarae, Cheris, \& Spender, Dale. (2000). "Feminism: Nineteenth Century." In Cheris Kramarae \& Dale Spender (Eds.), Routledge International Encyclo- 
pedia of Women: Global Women's Issues and Knowledge. New York: Routledge. 798-803.

Lloyd, Genevieve. (1993). The Man of Reason: "Male" and "Female" in Western Philosophy. London: Routledge.

Lugones, María. (2007). "Heterosexualism and the Colonial/Modern Gender System". Hypatia, 22(1), 186-219.

McKeon, Michael. (1995). "Historicizing Patriarchy: The Emergence of Gender Difference in England, 1660- 1760". Eighteenth-Century Studies, 28(3), 295-322.

McKeon, Michael. (2005) The Secret History of Domesticity: Public, Private, and the Division of Knowledge. Baltimore: Johns Hopkins University Press.

Merchant, Carolyn. (1989 [1980]). The Death of Nature: Women, Ecology, and the Scientific Revolution. San Francisco: Harper San Francisco.

MERRITT, Juliette. (2004). Beyond Spectacle: Eliza Haywood's Female Spectator. Toronto: University of Toronto Press.

Mies, Maria. (2014 [1986]). Patriarchy and Accumulation on a World Scale: Women in the International Division of Labour. London: Zed Books.

Mohanty, Chandra Talpade. (1984). "Under Western Eyes: Feminist Scholarship and Colonial Discourses Chandra Talpade Mohanty". boundary 2, 12(3), 333358. http://doi.org/10.2307/302821

MoretTI, Franco. (2003). "Graphs, Maps Trees: Abstract Models for Literary History-1." New Left Review, (24), 67-93.

NZEgwU, Nkiru Uwechia. (2006). Family Matters: Feminist Concepts in African Philosophy of Culture. Albany: State University of New York Press.

Outram, Dorinda. (2013). The Enlightenment. Cambridge: Cambridge University Press.

OYĚWÙMÍ, Oyèrónkẹ́. (1997). The Invention of Women. Minneapolis: University of Minnesota Press.

PotTer, Tiffany. (2003). "The Language of Feminised Sexuality: Gendered Voice in Eliza Haywood's Love in Excess and Fantomina." Women's Writing, 10(1), 169-186.

RABB, Melinda Alliker. (2007). Satire and Secrecy in English Literature from 16501750. New York: Palgrave Macmillan.

RuBIN, Gayle. (1984). "Thinking Sex: Notes for a Radical Theory of the Politics of Sexuality." In Carole Vance (Ed.), Pleasure and Danger. Boston: Routledge \& K. Paul.

Spedding, Patrick. (2003). A Bibliography of Eliza Haywood. London: Pickering \& Chatto.

SPENCER, Jane. (1986). The Rise of the Woman Novelist: From Aphra Behn to Jane Austen. New York: Blackwell.

Staves, Susan. (2006). A Literary History of Women's Writing in Britain, 1660 1789. Cambridge: Cambridge University Press. 